\title{
The sense of smell, its signalling pathways, and the dichotomy of cilia and microvilli in olfactory sensory cells Rebecca Elsaesser ${ }^{1}$ and Jacques Paysan*2
}

\author{
Address: ${ }^{1}$ Johns Hopkins University School of Medicine, 725 N. Wolfe St., 408 WBSB, Baltimore, MD 21205, USA and ${ }^{2}$ Technical University of \\ Darmstadt, Institute of Zoology, Schnittspahnstrasse 3, D-64287 Darmstadt, Germany \\ Email: Rebecca Elsaesser - selsaes3@jhmi.edu; Jacques Paysan* - paysan@bio.tu-darmstadt.de \\ * Corresponding author
}

Published: 18 September 2007

BMC Neuroscience 2007, 8(Suppl 3):SI doi:I0.II86/I47I-2202-8-S3-SI

This article is available from: http://www.biomedcentral.com/I47I-2202/8/S3/SI

(c) 2007 Elsaesser and Paysan; licensee BioMed Central Ltd.

This is an open access article distributed under the terms of the Creative Commons Attribution License (http://creativecommons.org/licenses/by/2.0), which permits unrestricted use, distribution, and reproduction in any medium, provided the original work is properly cited.

\begin{abstract}
Smell is often regarded as an ancillary perception in primates, who seem so dominated by their sense of vision. In this paper, we will portray some aspects of the significance of olfaction to human life and speculate on what evolutionary factors contribute to keeping it alive. We then outline the functional architecture of olfactory sensory neurons and their signal transduction pathways, which are the primary detectors that render olfactory perception possible. Throughout the phylogenetic tree, olfactory neurons, at their apical tip, are either decorated with cilia or with microvilli. The significance of this dichotomy is unknown. It is generally assumed that mammalian olfactory neurons are of the ciliary type only. The existance of so-called olfactory microvillar cells in mammals, however, is well documented, but their nature remains unclear and their function orphaned. This paper discusses the possibility, that in the main olfactory epithelium of mammals ciliated and microvillar sensory cells exist concurrently. We review evidence related to this hypothesis and ask, what function olfactory microvillar cells might have and what signalling mechanisms they use.
\end{abstract}

\section{The "scentimental" nose}

Wine experts occasionally identify a broad variety of aromas such as »bacon fat, pain grillé, black raspberries, cassis, white flowers, and Provençal olives" when they taste, for example, a vintage of Côte Rôtie [1]. Even an expert's nose, however, can get surprisingly confused in the presence of misleading visual cues. In a noteworthy study performed at the University of Bordeaux, Gil Morrot and collaborators asked 54 undergraduate students from the Faculty of Oenology to compare a glass of white Bordeaux wine (containing Sémillon and Sauvignon grapes) to a glass of exactly the same wine, which had been coloured by a mixture of red anthocyanins. Although the added anthocyanins had no perceptible taste or odour, the subjects identified remarkably different sets of aromas in both glasses [2]. Despite this surprising lack of discriminatory skills, it seems our sense of smell has other proficiencies, such as a remarkable power of attributing emotional qualities to objects that we see. The attributive nature of the sense of smell is illustrated by the fact that we need socalled descriptors to communicate odours [3]. What alternatives do we have but to portray an olfactory perception as "black raspberries-like», or "Provençal olives-like«? None of these scents can be addressed directly, without reference to its respective source [4]. Other perceptual qualities can often be named independently. We can speak, for example, of "red" and »sweet " without employing metaphors and similes such as "anthocyanin-like« or "sucrose-like». Odours, on the other hand, can affect our emotional state profoundly [5-7]. A gustatory stimulus, such as "too salty", effectively keeps us from drinking sea water, but compared to bad odours, the aversion evoked 
by the taste of salt is less affective. This is vividly illustrated by an authentic report by the early Gabriel Garcia Marquez, who describes the fate of a shipwrecked sailor who drifts on his raft through the Caribbean sea. After four days of suffering the agonies of thirst, he decides to drink salt water. "This water does not satisfy your thirst", the salvaged sailor later testifies, "but it refreshes" [8]. Apparently, the repulsion evoked by the salty taste is based on reflex and rational thinking rather than on emotional disgust. By the same token, sweetness alone will rarely make us long for artificial sweeteners and it is unlikely to evoke a similar savouriness as the scent of freshly baked bread. In contrast, the repulsiveness of the nauseating stench of rotting meat is so effective that the use of this smell was suggested as a powerful stimulus for therapeutical conditioning of sexual offenders $[9,10]$.

It seems that an important role of the human sense of smell is adding emotional qualities to situations and objects that we see, and not so much to making an essential contribution to finding or identifying things. Of course we can recognize typical odours even with our eyes shut, but the scent of ripe bananas, for example, rather influences our appetite than being necessary to distinguish bananas from pineapples. This observation raises questions about the biological purpose of the olfactory sense in a visually dominated species, such as man. What is so important about watering our mouth that it exerts sufficient selection pressure to sustain several hundreds of functional olfactory receptor genes through evolution? Why do we even maintain the ability to regenerate olfactory neurons from adult stem cells, just to make sure that our sense of smell stays alive as long as we do?

The functional anatomy of the mammalian nose and its close contact to the oral cavity point to possible answers to these questions. Odour molecules approach the olfactory epithelium along two principle routes: When we sniff or breathe with our mouth closed, the inhaled air enters the lumen of the nasal cavity through external nostrils. Food almost touches our nares before it enters the oral cavity, and it is almost impossible not to stick our nose into a glass of wine that we taste. When we chew, we break down the food into a mush from which favours exhale. These volatile odour molecules then travel up the retronasal passage and reach the olfactory epithelium through internal nostrils, which connect the pharynx to the nasal cavity [11]. The phylogenetic emergence of these internal nostrils (or choanae) was an important step in the adaptation of the olfactory system to air breathing [12]. It now enables us to employ olfactory perception in the assessment of nutrients at every level of uptake. We can now even evaluate compounds in our food that are made accessible only by mechanical exposure. This close involvement of the olfactory system in the analysis of food along with the attributive nature of olfactory perception allow us to employ the sense of smell in aquiring refined food preferences. In this respect, humans are uniquely flexible. There might be some inherently aversive odours (such as the smell of rotting meat), but depending on trends and cultural background, we can enjoy almost everything, from fried locusts spiced with salt and lime (as served in the Mexican region of Oaxaca) to live oysters (which are perceived as a delicacy in a lot of wealthy Western societies). We can even "learn to enjoy things that we should not enjoy" [13]. Used as flavoring agents, bitter compounds, including plant-derived phenols and polyphenols, flavonoids, catechins, and caffeine, enhance the sensory appeal of beverages and food, such as beer, coffee, chocolate, tea, and tonic water [14]. This flexibility effectively supports opening up new food resources. In this context, olfactory conditioning helps us to pass on approved food preferences to our infant offspring, while at the same time protecting them from exploring potentially noxious material while unattended (long before they understand the advise that we give). Cooking-ambitious parents often experience how cautious and how annoyingly conservative their children can be, when it comes to trying out unknown delicacies. The juveniles may well obstinately insist on fish sticks with mashed potatoes when served cod steaks cooked in an winteresting spice mixture of ginger, cloves, chilies, cilantro leaves, and lemon juice" [15]. Training pays out, however, and we can learn to expand our pool of nutrients to include surprisingly variable ingredients.

For free living rats, the importance of social learning of food preferences has also been demonstrated [16], and olfaction certainly plays an important role in this process [17]. Mice prefer sweet over bitter, even if the sweet perception is triggered erroneously by a bitter compound [18]. Humans, in contrast, are capable of expanding their menu well beyond sweet and non-bitter aliments, and they seem to do so by prioritizing hedonic odour qualities over gustatory perception, and by dynamically adapting their food preferences to changing age, resources, and trends.

The production of aromas and scents has long been an important economical factor [19] and an interesting perspective for biotechnological fabrication [20]. Olfactory signals can act as mediator of social interactions [21] and the potential of olfactory cues as marketing tools in social and economical context has long been recognized [2224]. Nevertheless, empirical research in the field of how we perceive odours is still fairly new, although we know more today about our brain's strategy in computing odour perception [25-28] than we did only a few years ago. Innovative techniques such as genetic tracing of neural circuits [29-31] and functional magnetic resonance imaging 
(fMRI) [32-36] produced exciting new results. It turns out, that, even in insects, coding and representation of odours is highly complex and dynamic [27,28,37-39], but significant progress is made, and, for example, we now begin to understand why a typical white wine tastes like a typical red wine, just because we added a tiny pinch of neutral anthocyanins. In a striking fMRI study, Jay Gottfried and Raymond Dolan recently found evidence of why "the nose smells what the eye sees". Their data indicate that the "human hippocampus mediates a reactivation of crossmodal semantic associations, even in the absence of explicit memory processing" [32,33]. Apparently, »black raspberries and Provençal olives « are imprinted in our brain, while the nose just pulls the trigger to unfold them in our mind.

\section{Olfactory sensory neurons}

The initial event in all these fascinating aspects of odour sensation is the binding of odorant molecules [40] to olfactory receptor proteins $[41,42]$. The released binding energy is transduced by a complex chain of molecular interactions into electrochemical membrane potentials, which dynamically modulate neuronal odour representation [19,43-56]. How do these primary olfactory processes work and where do they occur?

A crux of this matter are the bipolar chemosensory neurons in the olfactory epithelium of the nose. Olfactory neurons are based at the front line between the brain and the odour-containing air that we breathe. Their surface membrane can be divided into two major spatial compartments, which are separated by a belt of tight junctional proteins [57]. The basolateral surface membrane lies well protected inside of the olfactory epithelial tissue. It covers large part of the apical dendrite, the cell body, and an unbranched axon that projects to the brain. On the other hand, there is an apical surface membrane compartment, the size of which is comparable to that of the basal compartment. It is located externally, directly exposed to the air, and attached to the rest of the cell only through the nexus of a thin apical dendrite, which reaches into the lumen of the nasal cavity with its terminal knob. The apical surface membrane is embedded into mucus and airway surface fluid. These represent ionic and biochemical compartments, which are important for olfactory signal transduction [58,59], as well as for innate defense of all airway epithelial surfaces [60]. Disturbances of the composition of these fluids, e.g. by mutation of ion transport systems, can cause severe pathologies, including cystic fibrosis [61].

Through their apical membrane compartment, olfactory sensory neurons contact the ambient air. At this surface, they collect information about volatile odour molecules, and here odours are transduced into neuronal signals, which the brain can read and analyse [62-64]. The molecular machinery that mediates olfactory signal transduction has been thoroughly characterized. Briefly, volatile odour molecules bind to odorant receptors [65] and trigger the activation of $\mathrm{G}$-proteins $\left(\mathrm{G} \alpha_{\mathrm{olf}}\right)$ [47]. This in turn stimulates adenylyl cyclase (type III) activity [66], and the resulting rise of intracellular adenosine 3',5'-cyclic monophosphate (cAMP) opens cyclic nucleotide-gated (CNG) cation channels [67]. The elicited influx of $\mathrm{Ca}^{2+}$ from the extracellular space depolarizes the ciliary membrane and prompts a secondary opening of $\mathrm{Ca}^{2+}$-gated chloride channels. These are responsible for large part of the depolarizing current across the olfactory ciliary membrane $[68,69]$. The depolarizing nature of the induced chloride current is based on an unusually high intracellular chloride concentration in the cytoplasm and cilia of olfactory sensory neurons, which is replenished by sodium-potassium-chloride co-transporters (NKCC-1) in the basolateral surface membrane compartment [68,69]. Odourinduced signals are thought to be terminated as a result of multiple factors and mechanisms [70], although recent evidence indicates that the dwell-time of the receptorodorant complex might be too small for some inactivation processes to occur under physiological conditions [71].

Beside this main stream model of olfactory signal transduction survived a scuff resistant hypothesis, proposing Ins $\mathrm{P}_{3}$ as an alternative second messenger in olfaction $[50,72,73]$. The possibility of a supplementary signalling pathway in olfactory neurons was initially raised by a study, in which the authors found that in contrast to most odours, some potent odorants failed to induce cAMP when applied to isolated olfactory cilia in biochemical assays [74]. It was later found that these "non cAMP odours" induced InsP $\mathrm{P}_{3}$ instead $[75,76]$, and that odorant receptors coupled to either CAMP or InsP $\mathrm{P}_{3}$ when they were functionally expressed in insect cells, depending on the receptor's specificity for either "CAMP-" or "IP3-odours" [77]. Despite these findings, the resulting speculation around a possible duality of signalling pathways in olfactory neurons remained controversial $[49,78]$. The goose of InsP $_{3}$ as an alternative second messenger in olfactory neurons got cooked, when mutant mice that lacked functional expression of $\mathrm{G} \alpha_{\text {olf }}$ [79], adenylyl cyclase (type III) [80], and cyclic nucleotide-gated ion channels [81] came out anosmic for both CAMP- and Ins $\mathrm{P}_{3}$-odours. Consequently, many researchers began to accept that cAMP might be the sole excitatory second messenger in olfaction [82-84]. The evidence linking phosphoinositide-related signalling to the mammalian olfactory epithelium, however, remained orphaned. 


\section{Cilia and microvilli}

The apical surface membrane of olfactory sensory neurons is a platform that links the physical world of odour molecules to the mental world of odour perception. At this interface, the physiochemical properties of volatile compounds are transduced into the electrochemical membrane potentials, which modulate the information from which the brain constructs, for example, the aromas of "black raspberries" and "pain grillé". The apical surface membrane compartment therefore represents a most important cell organelle. It is significantly enlarged by cilia or microvilli, which emerge from the terminal knob of the apical dendrite to protrude into the mucus [85]. What is the biological significance of this enlargement? Why do some sensory neurons sustain this extension with cilia, while others possess microvilli or both?

A requirement for high sensitivity is often regarded as a sufficiently meaningful biological reason for the enlargement of the surface area of sensory membranes. In photoreceptor cells, this argument intuitively makes sense. A photon on its path through a photoreceptor cell is either captured by a photosensitive rhodopsin molecule or the information it carries will be lost by absorption in non sensory material. Therefore, photoreceptor cells increase their quantum efficiency by forming multilayered stacks of membranes that are tightly packed with photosensitive rhodopsin molecules. This functional cytoarchitecture can likewise be observed in vertebrate [86] and invertebrate eyes [87], where stacks of membrane discs or rhabdomeric microvilli ensure high quantum efficiency of each photosensitive cell. In the case of olfactory sensory neurons, however, the situation is slightly different. Compared to photons, odour molecules are stable and could theoretically be trapped and retained in a lipophilic environment until receptor activation has occurred. Furthermore, the physiological purpose of increasing sensitivity is also not as obvious as a first glance might suggest. It has been reported that olfactory neurons are sufficiently sensitive to detect even single odour molecules [88], but the biological significance of this finding was challenged $[49,89,90]$. Extraordinary sensitivity has undoubtedly been observed in the olfactory system of moths [91], but since only a few mammals fly around in the dark with a need to smell their food or mating partner from miles away, it remains unclear how solitary odour molecules could carry meaningful information and why they should be detected at all. Quantal sensitivity of olfactory neurons, similar to that observed in photoreceptor cells $[92,93]$, could also provide confusing sensory input to the brain. Olfactory neurons express only one or a few olfactory receptors [94,95] and many olfactory receptors are broadly tuned to overlapping sets of qualitatively distinct odour molecules [6264]. Thus, two identical solitary odour molecules could trigger different sensory input into the olfactory system, depending on which receptor they hit by chance. Such an arrangement does not appear like a plausible approach to ensure reliable and reproducible sensory input, particularly at extremely low levels of odorant concentration. Accordingly, in contrast to phototransduction, olfactory signal transduction lacks amplification at one of its very basic levels, namely that of receptor-G-protein-activation. The life-time of the receptor-odorant complex was found to be so short, that the complex might often dissociate even before a single G-protein was activated. Consequently, signal amplification by one active receptor triggering multiple downstream G-protein/effector enzyme molecules seems unplausible [71].

Alternative explanations for the observed enlargement of the apical membrane compartment of olfactory neurons include the outstanding ability of these cells to provide information that allows the detection of even minute differences between odour concentrations, or, equivalently, differential affinities of odour molecules to distinct receptor populations.

Even humans are capable of extracting spatial information from smell [96-98]. Dogs just need five footsteps to determine the direction of an odour trail [99] and a rat can determine the location of an odour source by stereo-localisation in a single sniff [100]. To enable such impressing performances, it will most likely be necessary to maximize the dynamic sensitivity of olfactory neurons. The dynamic sensitivity represents the ability of a signalling system to respond to a small change of the input signal by modulating the output signal in a statistically significant manner. The dynamic sensitivity of an olfactory neuron is directly influenced by the size of its apical membrane surface compartment, because the latter is correlated to the number of signalling proteins (i.e. receptor molecules, G-proteins, and ion channels) and thus to the total number of elementary responses that can simultaneously be generated in each cell.

The requirements to a high performance odorant detector can be illustrated by comparing it to a light detecting device, such as a charge-coupled device (CCD) camera. Here, each photosensitive element (analogous to an olfactory neuron in the nose) is characterized by its background noise, its quantum efficiency, and its full well capacity [101]. In a high performance CCD camera, noise reduction is achieved by cooling the sensor to low temperatures. Quantum efficiency of a photon detector describes the ratio between the number of photons registered by the detector to the number of photons entering the device. Lastly, the full well capacity of the photon detector describes the total number of photons that can be registered within a single readout cycle. To improve the dynamic sensitivity of any charge-coupled device, it is nec- 
essary to combine high quantum efficiency with a large full well capacity. If the ratio between full well capacity and quantum efficiency of the detector is low, the slope of its response curve will be shallow. This, in turn, makes it difficult to reliably detect minute differences in signal amplitude, particularly when background noise is high. Therefore, high performance light detectors require the optimization of all three parameters combined: low background noise, high quantum sensitivity, and large full well capacity.

For olfactory sensory neurons, similar requirements might apply. In the olfactory sytem, noise reduction is a multi level process [102]. It begins with a nonlinear signal amplification by $\mathrm{Ca}^{2+}$-activated chloride currents $[103,104]$, continues by the convergence of dozens of cilia onto the terminal knob of the sensory neuron's apical dendrite, and is further sophisticated by the convergence of hundreds of olfactory neurons on a single glomerulus in the olfactory bulb [105-107]. This multilevel integration with the possibility of adjusting thresholds at each level enables effective filtering of background noise, which has been observed as an intrinsic feature of olfactory signal transduction [102,108-111]. To represent high performance detectors for chemical constituents of the air, olfactory neurons might also have to improve quantum efficiency and full well capacity by enlarging their apical membrane compartment. At a given odour concentration and affinity of the odorant to its receptor, the quantum efficiency of the olfactory neuron as a whole will directly depend on the total number of receptors present. The same holds true for the neuron's "full well capacity", which represents its capacity to register odorant-to-receptor-docking-events within a single readout cycle (which in this case might be equivalent to the duration of a sniff). Since there is a limit to packaging density of receptors and other signaling molecules within the surface membrane, these parameters will also depend on the total apical surface membrane area. Olfactory neurons therefore enlarge this area by the folding the apical membrane into cilia and/or microvilli [85]. Interestingly, it seems that olfactory neurons further improve their physiological performance by additional measures. As mentioned above, the receptor-odorant dwell-time is very short, enabling repeated binding of odorant molecules to the same receptor. Furthermore, the quantal responses of olfactory neurons are very small. At the same time, the density of receptors in the ciliary membrane is so high that their response domains overlap, which causes non linear summation of the odour-induced unitary responses [71]. Since linearity is neither necessary for detecting differential activation patterns (i.e. specific odours), nor for sensing relative differences in odour concentration, this strategy seems to improve the dynamic resolution of each olfactory neuron over a broad range of odour concentra- tion levels and thus perfectly serves to the needs of a biological high performance chemodetector.

\section{Ciliary and microvillar (rhabdomeric) photoreceptor cells}

For animal photoreceptor cells, two types of membrane enlargement have been recognized. Rhabdomeric photoreceptor cells, as they occur in the compound eye of arthropods, carry microvilli, while the rods and cones of the mammalian retina and the light sensitive cells of the pineal organ are of a ciliary type. The evolutionary origin of both cell types was unclear [112], until Detlev Arendt and his collaborators found a polychaete marine worm, Platynereis dumerilii, which possesses both, rhabdomeric and ciliary photoreceptors [113]. On the basis of these findings, the authors proposed an attractive model for the evolution of metazoan photoreceptor cells. Accordingly, rhabdomeric and ciliary photoreceptors have emerged from a common ancestor that used an ancestral opsin for photodetection. The ancestral opsin gene then duplicated into the paralogs rhabdomeric opsin (r-opsin) and ciliary opsin (c-opsin), supporting the emergence of ciliated and rhabdomeric photoreceptor cells and their functional diversification. This dualism of light sensitive cells can also be observed within the mammalian retina. Melanopsin, the vertebrate ortholog of invertebrate r-opsin, is expressed in some light-sensitive retinal ganglion cells, which are involved in synchronizing the primary circadian pacemaker in the suprachiasmatic nucleus to the light-dark cycle [114].

Light transduction in invertebrates is mediated by an eyespecific phospholipase C (norpA), phosphatidylinositol 4,5-bisphosphate $\left(\mathrm{PIP}_{2}\right)$, its downstream products $\mathrm{InsP}_{3}$ and diacylglycerol [115-117], and transient receptor potential (TRP and TRPL) channels [118,119]. Interestingly, the vertebrate ortholog (PLC $\beta 4$ ) of norpA is also expressed in the mammalian retina [120] and melanopsin signalling has been linked to $\mathrm{InsP}_{3}$ in cultured Xenopus melanophores [121-124]. This raises the question, whether cells expressing r-opsin and its orthologs generally utilize phosphoinositides as second messengers. Although melanopsin-expressing retinal ganglion cells do neither appear to be normal retinal ganglion cells nor specialized rhabdomeric or microvillar sensory neurons $[125,126]$, this evidence nevertheless points towards a possible phylogenetic link between rhabdomeric photoreceptor cells and phosphoinositide-mediated signalling processes. In contrast, ciliary photoreceptors prefer phosphodiesterase-mediated signal transduction with cGMP as a second messenger [121,122].

A functional reason for the possible allocation between microvilli and $\mathrm{InsP}_{3}$ signalling has been proposed by Klaus Lange [127]. He suggested that F-actin, which is a major constituent of the cytoskeleton of microvilli, repre- 
sents an $\mathrm{InsP}_{3}$-sensitive, non vesicular $\mathrm{Ca}^{2+}$-store. Accordingly, a stimulation of phospholipase $\mathrm{C}$ will release the actin-binding proteins profilin and gelsolin from phospholipids, which in turn liberates $\mathrm{Ca}^{2+}$ from F-actin. InsP $\mathrm{P}_{3}$ stabilizes the active state of profilin/gelsolin. Furthermore, $\mathrm{PIP}_{2}$, a substrate of phospholipase $\mathrm{C}$, is preferentially localised to raft-like lipid domains, which are typically observed in conjunction with microvilli $[128,129]$. This raises the possibility that, for principle reasons, signal transduction processes in cilia and microvilli preferentially utilize cyclic nucleotides and phosphoinositides as second messengers, respectively.

\section{Ciliated and microvillar olfactory neurons}

In mammals, the apical cell surface of typical olfactory neurons is enlarged by a species-dependant number of cilia. In microvillar olfactory neurons the enlargement occurs by the folding of the membrane into microvilli. Both types of olfactory sensory neurons have been observed without perceivable phylogenetic boundaries throughout the clade of vertebrates. In her excellent and comprehensive review, Heather Eisthen pointed out that sharks, rays, and ratfish have only microvillar olfactory neurons, while lampreys, frogs, snakes, and turtles have only ciliated ones. In hagfish, bony fishes, and salamanders, both types of olfactory neurons can be observed next to each other, while in birds individual olfactory neurons simultaneously carry cilia and microvilli [85]. The situation in mammals is not entirely clear. Many researchers assume that only ciliated olfactory neurons are present, but the occurrence of microvillar olfactory neurons has also been proposed [130,131]. Surprisingly, this finding has never attracted much attention.

\section{Olfactory microvillar cells}

The olfactory epithelium of mammals consists of a relatively small number of cell types [132]. A monolayer of supporting or sustentacular cells separates the nasal cavity from the sensory neuroepithelium. This palisade-like monolayer covers a pseudostratified layer of bipolar sensory neurons, which basally project an axon to the olfactory bulb (Figure 1). Apically, the olfactory neurons contact the lumen of the nasal cavity with the terminal knob of their apical dendrite (Figure 2). Between the cell bodies of the chemosensory neurons and the basal lamina is a thin layer of so-called globose and horizontal basal cells, which contains a population of adult neuronal stem cells [133-136]. These stem cells are important to maintain function and histology of the olfactory epithelium, because based on their exposed situation in contact to ambient air, olfactory neurons are prone to damage and infection. Consequently, olfactory neurons have a limited lifetime before they are periodically replaced [137-141].
In addition to these three well established major olfactory epithelial cell types, i.e. ciliated olfactory sensory neurons, microvillous supporting or sustentacular cells, and basal cells, at least five classes of so-called olfactory microvillar cells exist [132]. To prevent confusion, Bert Menco and Edward Morrison suggested to systematically re-classify olfactory microvillar cells, and to combine all olfactory epithelial cells that have microvilli under the term "microvillous cells" [132]. The function of this peculiar type of cells is totally unknown.

Some microvillous cells have been proposed to represent a second class of bipolar sensory neurons. Based on an electron microscopic study of the olfactory epithelium of rat, François Jourdan first made this suggestion in 1975 [130]. In his thesis, he described a microvillar type of bipolar olfactory cells (type B cells), the morphology of which, in his view, was that of a typical bipolar receptor neuron (Figure 3). Similar cells were later reexamined by David Moran, Carter Rowley, and Bruce Jafek [131], who also found evidence that supported the existence of a second morphologically distinct class of bipolar sensory neurons in the mammalian olfactory epithelium [142,143]. The authors injected horseradish peroxidase into the olfactory bulb of rat and detected retrograde labelling of olfactory epithelial microvillar cell bodies. They concluded that microvillar cells are connected by an axon to the olfactory bulb, and that the rat olfactory system will thus "need to be expanded to include two morphologically distinct classes of sensory receptors, ciliated olfactory receptors and microvillar cells" [143]. This hypothesis seemed plausible on the basis of the observation that ciliated and microvillar olfactory neurons occur in many other species throughout the clade of vertebrates $[85,144]$. However, the evidence that microvillar cells are neuronal remained controversial. When Virginia Carr and collaborators stained rat olfactory epithelia with monoclonal antibody 1A-6, they labelled microvillar cells that were not immunoreactive with SUS-1 antibodies (which is a marker for supporting cells). The 1A- 6 immunoreactive cells, however, neither expressed olfactory marker protein (OMP), nor did they possess an identifiable axonal process. Since the cells also survived bulbectomyinduced degeneration of olfactory sensory neurons, the authors concluded that olfactory microvillar cells are of non-neuronal nature [145]. The absence of OMP in microvillar cells was confirmed by Edward Johnson and collaborators [146]. These authors also acknowledged some arguments that speak for a non-neuronal function of microvillar cells, but pointed out that the peroxidase backfill experiments [143] and the expression of Spot-35 protein [147] are in favour of positioning microvillar cells "in with known microvillar olfactory receptor cells of other vertebrates". They carefully concluded, that the 


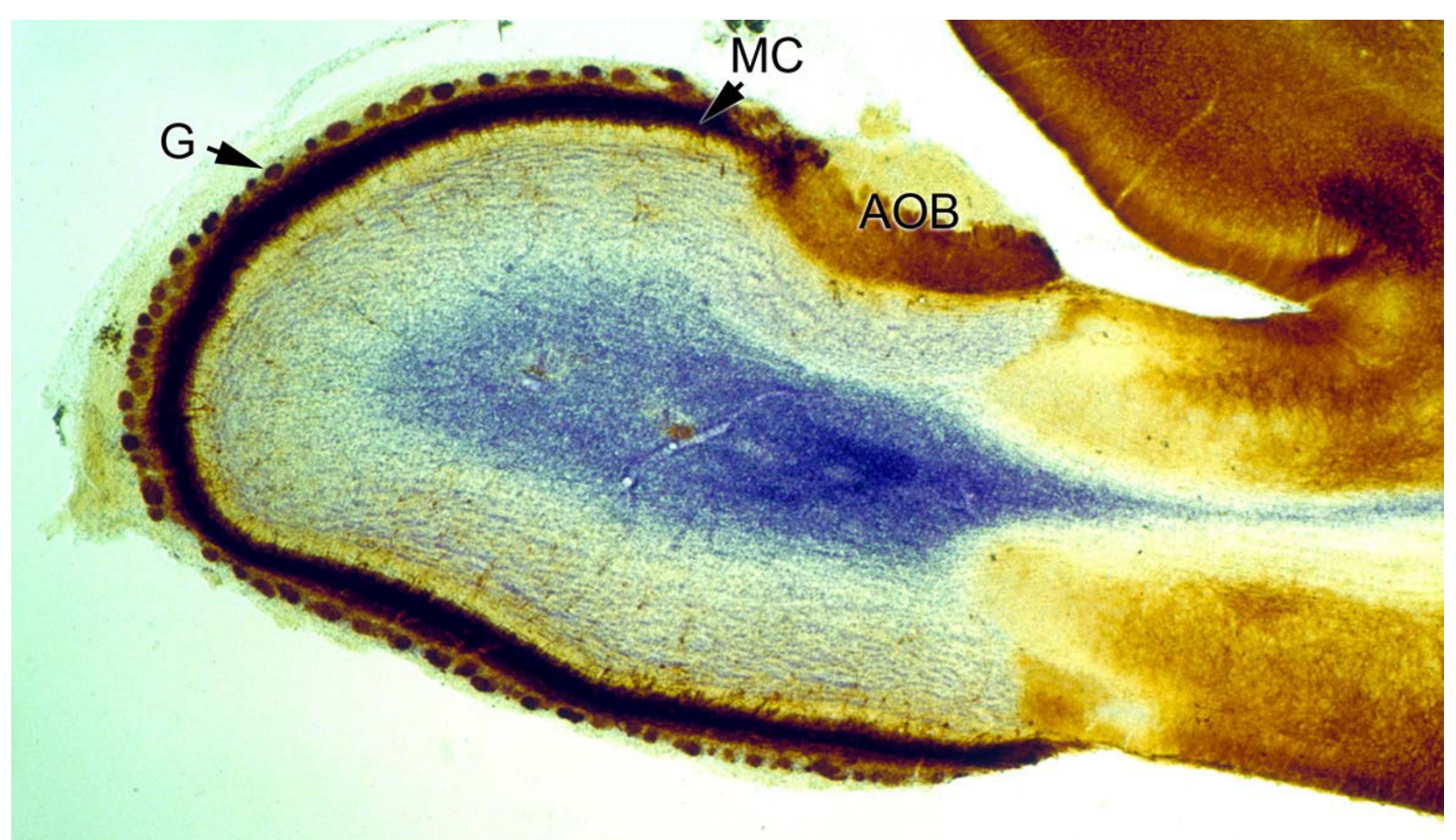

\section{Figure I}

Olfactory bulb. Section through the olfactory bulb of a 16 days old rat brain. The tissue has been fixed and immunoperoxidase-stained with antibodies against GABAA-receptor_I-subunit (brown) as described elsewhere [157]. NissI staining was performed to counter stain (blue). Clearly visible are the accessory olfactory bulb (AOB), to which chemosensory neurons from the vomeronasal organ project, the intensely labelled layer of mitral cells (MC), and the glomeruli (G), which represent the first relay station for sensory information transmitted from the nose to the brain (Jacques Paysan, unpublished).

function of the olfactory microvillar cell remains enigmatic [146].

Recently, we have examined the distribution of phosphoinositide-related signalling proteins in the mammalian olfactory epithelium and found that some elements of Ins $\mathrm{P}_{3}$-mediated signal transduction were found exclusively in olfactory microvillar cells $[19,148]$. These cells that we call "Jourdan cells", were labelled with antibodies against phospholipase $\mathrm{C}$ beta-2 (PLC $\beta 2$ ), type $3 \mathrm{InsP}_{3^{-}}$ receptors ( InsP $_{3} \mathrm{R}-\mathrm{III}$ ), type 6 transient receptor potential channels (TRPC6), and other proteins, including neuronal marker protein MAP2b [148]. In contrast, no coexpression with OMP, cyclic nucleotide-gated channels, or adenylyl cyclase could be detected. When dissociated and exposed in vitro to depolarizing concentrations of potassium chloride, Jourdan cells reacted with a transient increase of their intracellular $\mathrm{Ca}^{2+}$ concentration. A similar reaction was observed, when the cells were exposed to odours. They also possessed a basal axon-like protrusion, which raised the possibility that they in fact represent a second class of olfactory sensory neurons. In contrast to ciliated olfactory sensory neurons [149-151], however, microvillar cells did not degenerated upon bulbectomy. This has been interpreted as one argument for a non neuronal nature of olfactory microvillar cells [145,152].

Is there a duality of signalling pathways and sensory neurons in the mammalian olfactory epithelium, similar to the existence of ciliary and rhabdomeric photoreceptor cells? Unfortunately, it is too early to submit such an admittedly attractive proposal. At present, only a few arguments that can be brought in position to support any concept on what olfactory microvillar cells might do. First, these cells look like sensory neurons [130]. They show a strong bipolar asymmetry, with a distinctive array of microvilli protruding towards the nasal cavity at their apical pole, and an axon-like process, the distal extension of which often crosses the basal lamina and seems to join the submucosal tracts of the olfactory nerve [148]. This bipolar architecture of microvillar cells would at least be tailor made to enable the cells to collect signals at the olfactory 


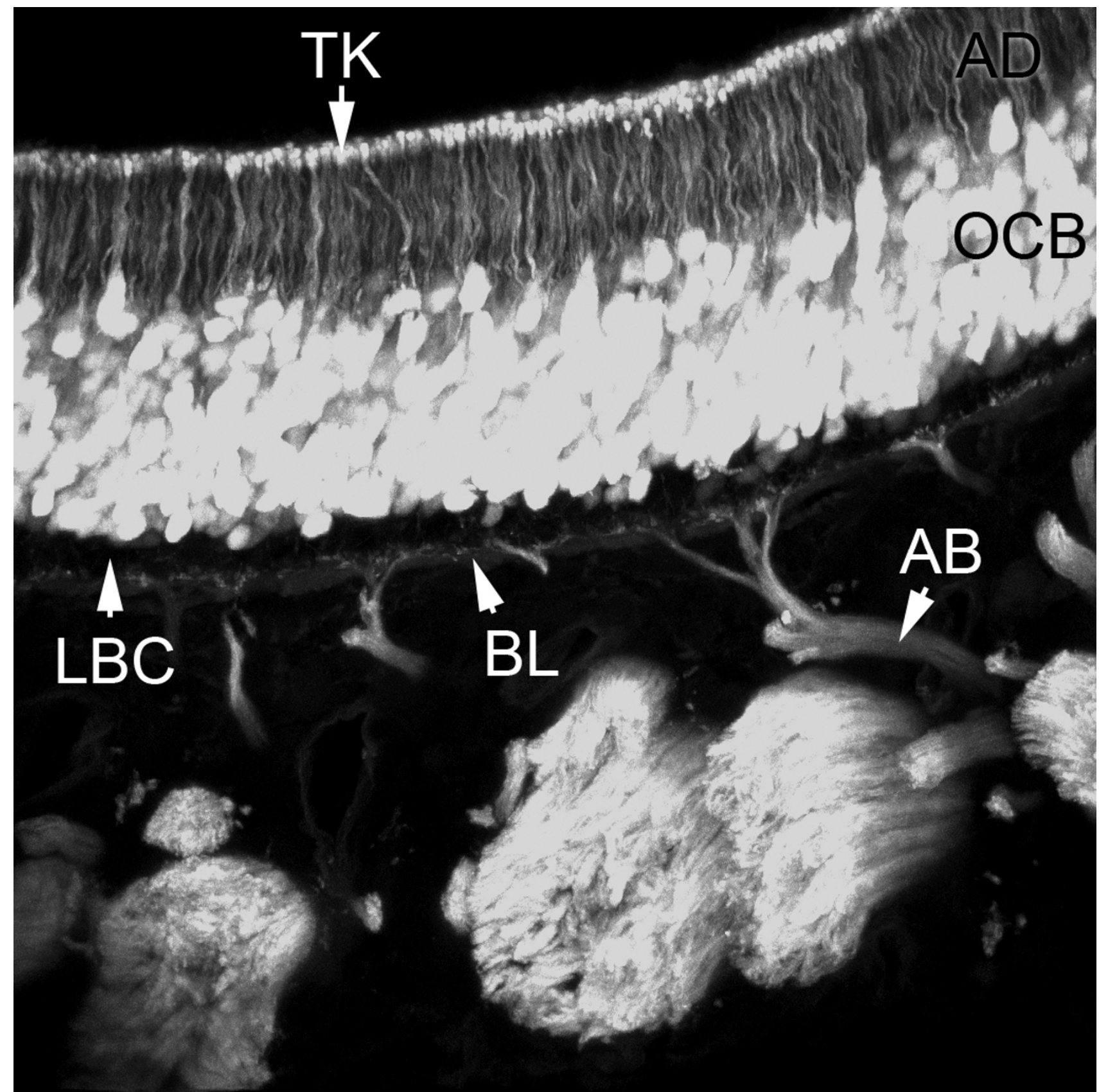

\section{Figure 2}

Olfactory epithelium. This image shows a vertical projection of a stack of confocal images taken from a transgenic mouse, in which green fluorescent protein (GFP) is expressed in all ciliated olfactory sensory neurons. GFP brightly labels the olfactory neuronal cell bodies (OCB), their apical dendrites (AD), and terminal knobs (TK). Staining does not extend into the sensory cilia, which remain invisible in this preparation. Basally to the olfactory neuronal cell bodies is the unstained layer of basal stem cells (LBC), from which degenerating neurons are constantly regenerated. The olfactory axons grow in bundles (AB) through the basal lamina (BL), and then fasciculate to form the tracts of the olfactory nerve, which projects into the brain. (Rebecca Elsaesser and Jacques Paysan, unpublished). 


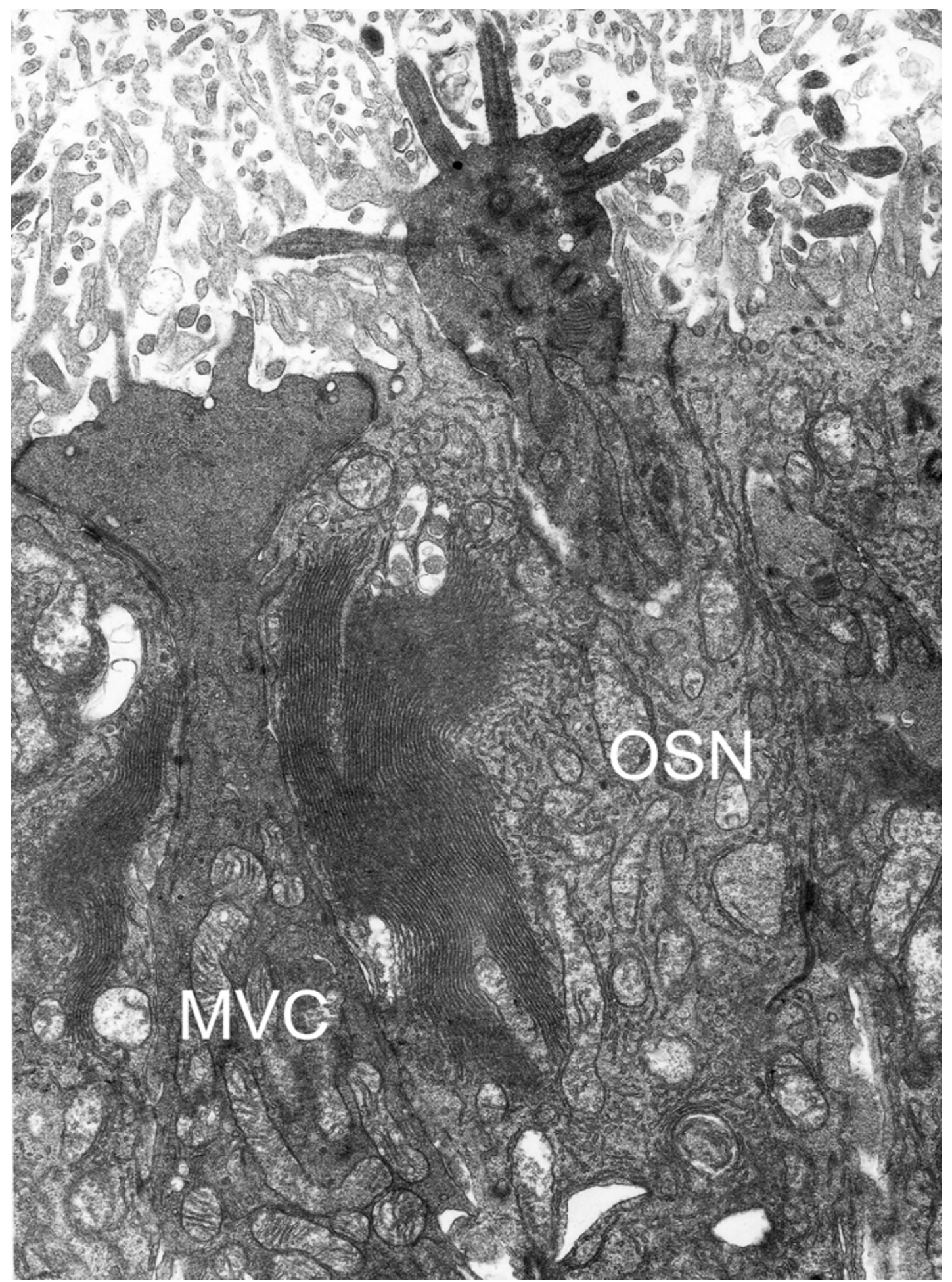

Figure 3

Microvillar and ciliated olfactory sensory cells. Electron micrograph showing the apical poles of an olfactory microvillar cell (MVC) and a typical olfactory sensory neuron (OSN). This image was generated in 1975 at the Centre de microscopie électronique (Claude Bernard University, Lyon I, France) and kindly provided by François Jourdan. See [130] for details. 
mucosal surface and transmit this information across the epithelium. This view is supported by the localization of PLC $\beta 2$ in the apical microvilli. PLC $\beta 2$ is a G-protein-activated signal transduction enzyme and thus points towards the presence of yet unidentified upstream G-protein-coupled receptors. Moreover, the cells express neuronal marker protein MAP2b [148], $\mathrm{Ca}^{2+-b i n d i n g ~ p r o t e i n ~}$ SPOT-35 [153], and they are depolarized by high potassium chloride [148]. All of these findings are compatible with a role of olfactory sensory neurons, but none of them is a persuasive argument. To determine, whether or not olfactory microvillar cells in fact represent sensory neurons, it will be necessary to characterize them by electrophysiological recordings and to analyze their cell morphology and gene expression profile in greater detail.

Albeit their (un)neuronal nature, we have now found evidence that points towards a possible function of olfactory microvillar cells. As pointed out above, olfactory sensory neurons periodically die by apoptosis, being constantly regenerated from a distinct population of adult neuronal stem cells. To avoid unproportional growth or degeneration of the olfactory epithelial tissue throughout life, both processes - cell death and regeneration - must be precisely coordinated over many decades. It has been demonstrated by Donna Hansel, Betty Eipper, and Gabriele Ronnett, that among the factors, which contribute to this control, are amidated neuropeptides [154]. In the adult olfactory neuroepithelium, neuropeptide $\mathrm{Y}$ is released from an uncharacterized set of cells [155]. We were now able to show that the NPY-expressing cells are identical to the olfactory microvillar cells that we had previously characterized [156]. This finding raises the possibility, that olfactory microvillar cells link signals on the surface of the olfactory mucosa to proliferation and differentiation of olfactory stem cells at the basis of the epithelium. Whether or not olfactory microvillar cells indeed represent a second class of olfactory sensory neurons remains elusive. In analogy to melanopsin-expressing retinal ganglion cells, they could be derived from an ancient type of microvillar olfactory neurons, which in the course of evolution have aquired a new physiological function. These thoughts, however, are totally speculative. Our efforts to understand their biological significance have just begun. A first step must be to unravel their input specificity by identifying the G-protein-coupled receptors, which act upstream of PLC $\beta 2$.

\section{Authors' contributions}

JP outlined the manuscript and wrote the initial draft. RE significantly contributed to its contents, figures, and to finalizing the manuscript. Both authors read and approved the final manuscript.

\section{Competing interests}

The authors have no competing interests.

\section{Acknowledgements}

This work was funded by the German Research Foundation (DFG). The authors thank François Jourdan, for kindly providing us with the electron micrograph shown in Fig. 2; Martin Meyer and Dagmar Püschel (Dolmetscher-Services, Wiesbaden), who supported us with valuable linguistic advise; Peter Mombaerts, for allowing us to work with the OMP-GFP mice; and Stefania Petrucco and Roberto Tirindelli, for their charming hospitality and critical input.

This article has been published as part of BMC Neuroscience Volume 8 Supplement 3, 2007: The chemical senses: recent advances and new promises. The full contents of the supplement are available online at http:// www.biomedcentral.com/I47I-2202/8? issue=S3.

\section{References}

I. McCoy E: The emperor of wine : the rise of Robert M. Parker, Jr. and the reign of American taste Ist edition. New York: ECCO; 2005.

2. Morrot G, Brochet F, Dubourdieu D: The color of odors. Brain Lang 200I, 79(2):309-320.

3. Cain WS: Know with the Nose - Keys to Odor Identification. Science 1979, 203(4379):467-470.

4. Dravnieks A, Masurat T, Lamm RA: Hedonics of Odors and Odor Descriptors. Journal of the Air Pollution Control Association 1984, 34(7):752-755.

5. Zald DH, Pardo JV: Emotion, olfaction, and the human amygdala: Amygdala activation during aversive olfactory stimulation. Proceedings of the National Academy of Sciences of the United States of America 1997, 94(8):41 19-4I24.

6. Alaouilsmaili O, VernetMaury E, Dittmar A, Delhomme G, Chanel I: Odor hedonics: Connection with emotional response estimated by autonomic parameters. Chemical Senses 1997, 22(3):237-248.

7. Vernet-Maury E, Alaoui-Ismaili O, Dittmar A, Delhomme G, Chanel J: Basic emotions induced by odorants: a new approach based on autonomic pattern results. Journal of the Autonomic Nervous System 1999, 75(2-3): 176-183.

8. García Márquez G: The story of a shipwrecked sailor : who drifted on a life raft for ten days without food or water, was proclaimed a national hero, kissed by beauty queens, made rich through publicity, and then spurned by the government and forgotten for all time. Ist Vintage Books edition New York: Vintage Books; 1987.

9. Maletzky BM, Steinhauser C: Olfactory aversion and its mechanism of action represents an excellent summary of this useful technique. Sex Abuse 2003, I5(3):2I5-217.

10. Laws DR: Olfactory aversion: notes on procedure, with speculations on its mechanism of effect. Sex Abuse 200I, 13(4):275-287.

11. Robinson J, Robinson J: How to taste : a guide to enjoying wine New York: Simon \& Schuster; 2000

12. Zhu M, Ahlberg PE: The origin of the internal nostril of tetrapods. Nature 2004, 432(7013):94-97.

13. Zuker CS: Neuron Satellite Meeting. Washington DC. 2005.

14. Drewnowski A: The science and complexity of bitter taste. Nutrition Reviews 200I, 59(6): 163-169.

15. Octopus Publishing Group Limited: Complete Indian Cooking. U.S. edition. London New York, NY: Hamlyn; 1999.

16. Galef BG, Lee WY, Whiskin EE: Lack of interference in longterm memory for socially learned food preferences in rats (Rattus norvegicus). Journal of Comparative Psychology 2005, I I 9(2): $13 \mid-135$.

17. Baker BJ, Booth DA: Genuinely Olfactory Preferences Conditioned by Protein Repletion. Appetite 1989, I3(3):223-227.

18. Mueller KL, Hoon MA, Erlenbach I, Chandrashekar J, Zuker CS, Ryba NJP: The receptors and coding logic for bitter taste. Nature 2005, 434(7030):225-229.

19. Elsaesser R, Paysan A: Morituri te salutant? Olfactory signal transduction and the role of phosphoinositides. Journal of Neurocytology 2005, 34(I-2):97-I I6. 
20. Hrazdina G: Aroma production by tissue cultures. J Agric Food Chem 2006, 54(4): I I 16-II 23.

21. Lin DY, Zhang SZ, Block E, Katz LC: Encoding social signals in the mouse main olfactory bulb. Nature 2005, 434(7032):470-477.

22. Brun JP: The production of perfumes in antiquity: The cases of Delos and Paestum. American Journal of Archaeology 2000, 104(2):277-308.

23. Debonoayrout J: Perfume-Making in Ancient Egypt. Historia 1995, 588:48-53.

24. Mitchell MA, Edman WW, Konigsbacher KS: Importance of Odor as Nonfunctional Component or Odor-Tool of Marketing. Annals of the New York Academy of Sciences 1964, I I 6(A2):685.

25. Zou ZH, Buck LB: Combinatorial effects of odorant mixes in olfactory cortex. Science 2006, 3 I I (5766): | $477-|48|$.

26. Zou ZH, Li FS, Buck LB: Odor maps in the olfactory cortex. Proceedings of the National Academy of Sciences of the United States of America 2005, 102(2I):7724-7729.

27. Laurent G: A systems perspective on early olfactory coding. Science 1999, 286(5440):723-728.

28. Laurent G: Olfactory network dynamics and the coding of multidimensional signals. Nature Reviews Neuroscience 2002, 3(II):884-895.

29. Horowitz LF, Montmayeur JP, Echelard Y, Buck LB: A genetic approach to trace neural circuits. Proceedings of the National Academy of Sciences of the United States of America 1999. 96(6):3194-3199.

30. Zou ZH, Horowitz LF, Montmayeur JP, Snapper S, Buck LB: Genetic tracing reveals a stereotyped sensory map in the olfactory cortex. Nature 200I, 4|4(6860): I73-I79.

31. Boehm U, Zou ZH, Buck LB: Feedback loops link odor and pheromone signaling with reproduction. Cell 2005 , I 23(4):683-695

32. Gottfried JA, Dolan RJ: The nose smells what the eye sees: Crossmodal visual facilitation of human olfactory perception. Neuron 2003, 39(2):375-386

33. Gottfried JA, Smith APR, Rugg MD, Dolan RJ: Remembrance of odors past: Human olfactory cortex in cross-modal recognition memory. Neuron 2004, 42(4):687-695.

34. Gottfried JA, Winston JS, Dolan RJ: Dissociable codes of odor quality and odorant structure in human piriform cortex. Neuron 2006, 49(3):467-479.

35. Osterbauer RA, Matthews PM, Jenkinson M, Beckmann CF, Hansen PC, Calvert GA: Color of scents: Chromatic stimuli modulate odor responses in the human brain. Journal of Neurophysiology 2005, 93(6):3434-344I.

36. Castriota-Scanderbeg A, Hagberg GE, Cerasa A, Committeri G, Galati G, Patria F, Pitzalis S, Caltagirone C, Frackowlak R: The appreciation of wine by sommeliers: a functional magnetic resonance study of sensory integration. Neuroimage 2005, 25(2):570-578.

37. Laurent G: Olfactory processing: maps, time and codes. Current Opinion in Neurobiology 1997, 7(4):547-553.

38. Laurent $\mathrm{G}$, Wehr M, Davidowitz $\mathrm{H}$ : Temporal representations of odors in an olfactory network. Journal of Neuroscience 1996, I 6(I 2):3837-3847.

39. Stopfer M, Jayaraman V, Laurent $\mathrm{G}$ : Intensity versus identity coding in an olfactory system. Neuron 2003, 39(6):991-1004.

40. Amoore JE: Odor theory and odor classification. In Fragrance chemistry : the science of the sense of smell Edited by: Theimer ET. New York: Academic Press; 1982:27-76.

4I. Buck L, Axel R: A novel multigene family may encode odorant receptors: a molecular basis for odor recognition. Cell I99I, 65(I): $175-187$.

42. Chess A, Buck L, Dowling MM, Axel R, Ngai J: Molecular biology of smell: expression of the multigene family encoding putative odorant receptors. Cold Spring Harb Symp Quant Biol 1992, 57:505-516.

43. Touhara K: Odor discrimination by $\mathbf{G}$ protein-coupled olfactory receptors. Microsc Res Tech 2002, 58(3): |35-|4|.

44. Serizawa S, Miyamichi K, Sakano $\mathrm{H}$ : One neuron-one receptor rule in the mouse olfactory system. Trends Genet 2004, 20(1 2):648-653.

45. Reed RR: After the holy grail: establishing a molecular basis for Mammalian olfaction. Cell 2004, I I 6(2):329-336.
46. Matthews HR, Reisert J: Calcium, the two-faced messenger of olfactory transduction and adaptation. Curr Opin Neurobiol 2003, 13(4):469-475.

47. Ronnett GV, Moon C: G proteins and olfactory signal transduction. Annu Rev Physiol 2002, 64:189-222.

48. Frings S: Chemoelectrical signal transduction in olfactory sensory neurons of air-breathing vertebrates. Cell Mol Life Sci 200 I, 58(4):510-519.

49. Gold $\mathrm{GH}$ : Controversial issues in vertebrate olfactory transduction. Annu Rev Physiol 1999, 61:857-87I.

50. Schild D, Restrepo D: Transduction mechanisms in vertebrate olfactory receptor cells. Physiol Rev 1998, 78(2):429-466.

5I. Ebrahimi FA, Chess A: Olfactory G proteins: simple and complex signal transduction. Curr Biol 1998, 8(I 2):R43|-433.

52. Firestein $\mathrm{S}$ : How the olfactory system makes sense of scents. Nature 200I, 4I3(6852):2II-2I8.

53. Menini A, Lagostena L, Boccaccio A: Olfaction: from odorant molecules to the olfactory cortex. News Physiol Sci 2004, 19:101-104.

54. Paysan J, Breer $\mathrm{H}$ : Molecular physiology of odor detection: current views. Pflugers Archiv-European Journal of Physiology 200I, 44 I (5):579-586.

55. Buck LB: Olfactory receptors and odor coding in mammals. Nutr Rev 2004, 62(I I Pt 2):SI84- I88. discussion S224-I4I

56. Mombaerts P, Wang F, Dulac C, Vassar R, Chao SK, Nemes A, Mendelsohn M, Edmondson J, Axel R: The molecular biology of olfactory perception. Cold Spring Harb Symp Quant Biol 1996, 61:135-145

57. Menco BPM: Ciliated and Microvillous Structures of Rat Olfactory and Nasal Respiratory Epithelia - a Study Using UltraRapid Cryo-Fixation Followed by Freeze-Substitution or Freeze-Etching. Cell and Tissue Research 1984, 235(2):225-24I.

58. Reuter D, Zierold K, Schroder W, Frings S: Contribution of chloride to receptor current in olfactory neurons: Cl-equilibrium potential and ionic composition of olfactory mucus. European Journal of Neuroscience 1998, 10:360-360.

59. Reuter D, Zierold K, Schroder WH, Frings S: A depolarizing chloride current contributes to chemoelectrical transduction in olfactory sensory neurons in situ. Journal of Neuroscience 1998 , I 8(1 7):6623-6630.

60. Smith JJ, Travis SM, Greenberg EP, Welsh MJ: Cystic fibrosis airway epithelia fail to kill bacteria because of abnormal airway surface fluid. Cell 1996, 85(2):229-236.

6I. Tarran R, Trout L, Donaldson SH, Boucher RC: Soluble mediators, not cilia, determine airway surface liquid volume in normal and cystic fibrosis superficial airway epithelia. Journal of General Physiology 2006, I 27(5):59|-604.

62. Duchamp-Viret $\mathrm{P}$, Chaput MA, Duchamp A: Odor response properties of rat olfactory receptor neurons. Science 1999, 284(5423):2|7|-2|74.

63. Duchamp-Viret P, Duchamp A, Chaput MA: Peripheral odor coding in the rat and frog: Quality and intensity specification. Journal of Neuroscience 2000, 20(6):2383-2390.

64. Duchamp-Viret P, Duchamp A, Chaput MA: Single olfactory sensory neurons simultaneously integrate the components of an odour mixture. European Journal of Neuroscience 2003, I 8(10):2690-2696

65. Mombaerts P: Molecular biology of odorant receptors in vertebrates. Annu Rev Neurosci 1999, 22:487-509.

66. Pace U, Hanski E, Salomon Y, Lancet D: Odorant-sensitive adenylate cyclase may mediate olfactory reception. Nature 1985, 31 6(6025):255-258.

67. Kaupp UB, Seifert R: Cyclic nucleotide-gated ion channels. Physiol Rev 2002, 82(3):769-824.

68. Restrepo D: The ins and outs of intracellular chloride in olfactory receptor neurons. Neuron 2005, 45(4):48I-482.

69. Reisert J, Lai J, Yau KW, Bradley J: Mechanism of the excitatory Cl-response in mouse olfactory receptor neurons. Neuron 2005, 45(4):553-561.

70. Zufall $F$, Leinders-Zufall $\mathrm{T}$ : The cellular and molecular basis of odor adaptation. Chem Senses 2000, 25(4):473-48I.

7I. Bhandawat V, Reisert J, Yau KW: Elementary response of olfactory receptor neurons to odorants. Science 2005, 308(5730): 1931-1934. 
72. Ache BW, Zhainazarov A: Dual 2Nd-Messenger Pathways in Olfactory Transduction. Current Opinion in Neurobiology 1995, 5(4):46I-466.

73. Breer $\mathrm{H}: \mathbf{2 N d}$ Messenger Signaling in Olfaction. Ciba Foundation Symposia 1993, I79:97-II4.

74. Sklar PB, Anholt RR, Snyder SH: The odorant-sensitive adenylate cyclase of olfactory receptor cells. Differential stimulation by distinct classes of odorants. J Biol Chem 1986, 26 I (33): I 5538-I5543.

75. Boekhoff I, Tareilus E, Strotmann J, Breer H: Rapid activation of alternative second messenger pathways in olfactory cilia from rats by different odorants. Embo / 1990, 9(8):2453-2458.

76. Breer H, Boekhoff I, Tareilus E: Rapid kinetics of second messenger formation in olfactory transduction. Nature 1990, 345(6270):65-68

77. Raming K, Krieger J, Strotmann J, Boekhoff I, Kubick S, Baumstark C, Breer $\mathrm{H}$ : Cloning and expression of odorant receptors. Nature I993, 36 I(64I 0):353-356.

78. Barinaga M: Mutant mice and worms help solve mysteries of olfaction. Science 1996, 274(5287):500-50I.

79. Belluscio L, Gold GH, Nemes A, Axel R: Mice deficient in G(olf) are anosmic. Neuron 1998, 20(I):69-8I.

80. Wong ST, Trinh K, Hacker B, Chan GC, Lowe G, Gaggar A, Xia Z, Gold GH, Storm DR: Disruption of the type III adenylyl cyclase gene leads to peripheral and behavioral anosmia in transgenic mice. Neuron 2000, 27(3):487-497.

8I. Brunet LJ, Gold GH, Ngai J: General anosmia caused by a targeted disruption of the mouse olfactory cyclic nucleotidegated cation channel. Neuron 1996, I 7(4):68I-693.

82. Barry PH: The relative contributions of CAMP and InSP3 pathways to olfactory responses in vertebrate olfactory receptor neurons and the specificity of odorants for both pathways. Journal of General Physiology 2003, I 22(3):247-250.

83. Takeuchi H, Imanaka $\mathrm{Y}$, Hirono J, Kurahashi T: Cross-adaptation between olfactory responses induced by two subgroups of odorant molecules. Journal of General Physiology 2003, I 22(3):255-264

84. Chen S, Lane AP, Bock R, Leinders-Zufall T, Zufall F: Blocking adenylyl cyclase inhibits olfactory generator currents induced by "IP(3)-odors". J Neurophysiol 2000, 84(I):575-580

85. Eisthen HL: Phylogeny of the Vomeronasal System and of Receptor Cell-Types in the Olfactory and Vomeronasal Epithelia of Vertebrates. Microsc Rese Tech 1992, 23(I):I-2I.

86. Carter-Dawson LD, LaVail MM: Rods and cones in the mouse retina. I. Structural analysis using light and electron microscopy. J Comp Neurol 1979, I 88(2):245-262.

87. Lee RD, Thomas CF, Marietta RG, Stark WS: Vitamin A, visual pigments, and visual receptors in Drosophila. Microsc Res Tech 1996, 35(6):418-430.

88. Menini A, Picco C, Firestein S: Quantal-Like Current Fluctuations Induced by Odorants in Olfactory Receptor-Cells. Nature 1995, 373(65 I 3):435-437.

89. Gold GH, Lowe G: Single Odorant Molecules. Nature 1995, 376(6535):27-27.

90. Lowe G, Gold GH: Olfactory Transduction Is Intrinsically Noisy. Proceedings of the National Academy of Sciences of the United States of America 1995, 92(I 7):7864-7868.

91. Angioy AM, Desogus A, Barbarossa IT, Anderson P, Hansson BS: Extreme sensitivity in an olfactory system. Chemical Senses 2003, 28(4):279-284.

92. Henderson SR, Reuss H, Hardie RC: Single photon responses in Drosophila photoreceptors and their regulation by $\mathrm{Ca} 2+$. J Physiol 2000, 524(I): I79-194.

93. Scott K, Zuker CS: Assembly of the Drosophila phototransduction cascade into a signalling complex shapes elementary responses. Nature 1998, 395(6704):805-808.

94. Firestein S: A code in the nose. SCi STKE 2004, 2004(227):pe I5.

95. Spehr M, Leinders-Zufall T: One neuron - multiple receptors: increased complexity in olfactory coding? SCi STKE 2005, 2005(285):pe25.

96. Porter J, Anand T, Johnson B, Khan RM, Sobel N: Brain mechanisms for extracting spatial information from smell. Neuron 2005, 47(4):58I-592.

97. Gottfried JA: A truffle in the mouth is worth two in the bush: odor localization in the human brain. Neuron 2005 47(4):473-476.
98. Small DM, Gerber JC, Mak YE, Hummel T: Differential neural responses evoked by orthonasal versus retronasal odorant perception in humans. Neuron 2005, 47(4):593-605.

99. Hepper PG, Wells DL: How many footsteps do dogs need to determine the direction of an odour trail? Chem Senses 2005, 30(4):29I-298.

100. Rajan R, Clement JP, Bhalla US: Rats smell in stereo. Science 2006 , 3 I I (576I):666-670.

I0I. Prettyjohns KN: Imaging Arrays, Solid State. Encyclopedia of physical science and technology 1992, 7:797-810.

102. Kleene SJ: High-gain, low-noise amplification in olfactory transduction. Biophysical Journal 1997, 73(2): I I I0-III7.

103. Lowe G, Gold GH: Nonlinear Amplification by CalciumDependent Chloride Channels in Olfactory Receptor-Cells. Nature 1993, 366(6452):283-286.

104. Lowe G, Gold GH: Nonlinear Amplification by CalciumDependent Chloride Channels in Olfactory Receptor-Cells. Biophysical Journal 1994, 66(2):A100-a 100

105. Franks KM, Isaacson JS: Strong single-fiber sensory inputs to olfactory cortex: Implications for olfactory coding. Neuron 2006, 49(3):357-363

106. Mori K, Nagao H, Yoshihara Y: The olfactory bulb: Coding and processing of odor molecule information. Science 1999 286(5440):7II-7I5.

107. Mombaerts P, Wang F, Dulac C, Chao SK, Nemes A, Mendelsohn M, Edmondson J, Axel R: Visualizing an olfactory sensory map. Cell 1996, 87(4):675-686

108. Lowe $\mathrm{G}$, Gold $\mathrm{GH}$ : Olfactory transduction is intrinsically noisy. Chemical Senses 1995, 20(6): 174-174.

109. Ahn SM, Freeman WJ: Neural Dynamics under Noise in Olfactory System. Biological Cybernetics 1975, I 7(3): I65-168.

I I0. Cain WS: Noise at Nose - Limitations on Olfactory Discrimination. Bulletin of the Psychonomic Society I976, 8(4):249-249.

III. Kleene S], Larsson HP, Lecar H: Noise analysis of CAMP- and $\mathrm{Ca2+-gated} \mathrm{channels} \mathrm{in} \mathrm{isolated} \mathrm{olfactory} \mathrm{cilia.} \mathrm{Chemical} \mathrm{Senses}$ 1995, 20(6): | $43-143$.

112. Arendt D: Evolution of eyes and photoreceptor cell types. International Journal of Developmental Biology 2003, 47(7-8):563-57I.

113. Arendt D, Tessmar-Raible K, Snyman H, Dorresteijn AW, Wittbrodt J: Ciliary photoreceptors with a vertebrate-type opsin in an invertebrate brain. Science 2004, 306(5697):869-87I.

1 4. Hattar S, Liao HW, Takao M, Berson DM, Yau KW: Melanopsincontaining retinal. ganglion cells: Architecture, projections, and intrinsic photosensitivity. Science 2002, 295(5557): 1065-1070.

I 15. Pak WL, Grossfie J, White NV: Nonphototactic Mutants in a Study of Vision of Drosophila. Nature 1969, 222(5 I9I):35I

116. Bloomquist BT, Shortridge RD, Schneuwly S, Perdew M, Montell C Steller H, Rubin G, Pak WL: Isolation of a Putative Phospholipase-C Gene of Drosophila, Norpa, and Its Role in Phototransduction. Cell 1988, 54(5):723-733.

I 17. Montell C: Visual transduction in Drosophila. Annu Rev Cell Dev Biol 1999, | 5:23|-268.

I 18. Montell C: TRP channels in Drosophila photoreceptor cells. J Physiol 2005, 567(Pt I):45-5I

1 19. Montell C, Rubin GM: Molecular Characterization of the Drosophila Trp Locus - a Putative Integral Membrane-Protein Required for Phototransduction. Neuron 1989, 2(4): |3 |3-1323.

120. liang HP, Lyubarsky A, Dodd R, Vardi N, Pugh E, Baylor D, Simon MI, Wu DQ: Phospholipase $C$ beta 4 is involved in modulating the visual response in mice. Proceedings of the National Academy of Sciences of the United States of America 1996, 93(25):|4598-|460I.

I2I. Isoldi MC, Rollag M, Castrucci AM, Provencio I: Melanopsin signals through a phosphoinositide pathway. Investigative Ophthalmology \& Visual Science 2005, 46:.

122. Isoldi MC, Rollag MD, Castrucci AMD, Provencio I: Rhabdomeric phototransduction initiated by the vertebrate photopigment melanopsin. Proc Natl Acad Sci U S A 2005, I 02(4): I 21 7-I 22 I.

123. Panda S, Nayak SK, Campo B, Walker JR, Hogenesch JB, Jegla T: Illumination of the melanopsin signaling pathway. Science 2005 , 307(5709):600-604.

I24. Qiu XD, Kumbalasiri T, Carlson SM, Wong KY, Krishna V, Provencio I, Berson DM: Induction of photosensitivity by heterologous expression of melanopsin. Nature 2005, 433(7027):745-749. 
125. Hattar S, Kumar M, Park A, Tong P, Tung J, Yau KW, Berson DM: Central projections of melanopsin-expressing retinal ganglion cells in the mouse. J Comp Neurol 2006, 497(3):326-349.

126. Hattar S, Liao HW, Takao M, Berson DM, Yau KW: Melanopsincontaining retinal ganglion cells: architecture, projections, and intrinsic photosensitivity. Science 2002 295(5557): 1065-1070.

127. Lange K: Microvillar Ca++ signaling: A new view of an old problem. Journal of Cellular Physiology 1999, I 80(1):19-34.

128. Martin TFJ: $\mathbf{P I}(4,5) \mathrm{P}-2$ regulation of surface membrane traffic. Current Opinion in Cell Biology 200I, I3(4):493-499.

129. Hansen GH, Immerdal L, Thorsen E, Niels-Christiansen LL, Nystrom $\mathrm{BT}$, Demant EJ, Danielsen EM: Lipid rafts exist as stable cholesterol-independent microdomains in the brush border membrane of enterocytes. J Biol Chem 200I, 276(34):32338-32344.

130. Jourdan F: Ultrastructural Study of Olfactory Epithelium of Rat - Occurrence of Several Morphological Types of Receptor Cells. Comptes Rendus Hebdomadaires Des Seances De L Academie Des Sciences Serie D 1975, 280(4):443.

131. Moran DT, Rowley JC, Jafek BW: Electron-Microscopy of Human Olfactory Epithelium Reveals a New Cell Type - the Microvillar Cell. Brain Research 1982, 253(I-2):39-46.

132. Menco BPM, Morrison EE: Morphology of the mammalian olfactory epithelium: form, fine structure, function, and pathology. In Handbook of olfaction and gustation 2 nd edition. Edited by: Doty RL. New York: Marcel Dekker; 2003: $17-49$.

133. Calof AL, Mumm JS, Rim PC, Shou JY: The neuronal stem cell of the olfactory epithelium. Journal of Neurobiology 1998, 36(2): 190-205.

134. Murrell W, Feron F, Wetzig A, Cameron N, Splatt K, Bellette B, Bianco J, Perry C, Lee G, Mackay-Sim A: Multipotent stem cells from adult olfactory mucosa. Developmental Dynamics 2005, 233(2):496-5I5.

135. Caggiano M, Kauer JS, Hunter DD: Globose Basal Cells Are Neuronal Progenitors in the Olfactory Epithelium - a Lineage Analysis Using a Replication-Incompetent Retrovirus. Neuron 1994, I 3(2):339-352.

136. Chen XY, Fang HS, Schwob JE: Multipotency of purified, transplanted globose basal cells in olfactory epithelium. Journal of Comparative Neurology 2004, 469(4):457-474.

137. Farbman Al, Buchholz JA, Suzuki Y, Coines A, Speert D: A molecular basis of cell death in olfactory epithelium. J Comp Neurol I999, 4I4(3):306-314.

138. Suzuki Y: Fine structural aspects of apoptosis in the olfactory epithelium. I Neurocytol 2004, 33(6):693-702.

139. Suzuki Y, Takeda M, Obara N, Suzuki N, Takeichi N: Olfactory epithelium consisting of supporting cells and horizontal basal cells in the posterior nasal cavity of mice. Cell Tissue Res 2000, 299(3):3।3-325.

140. Moulton DG: Dynamics of cell populations in the olfactory epithelium. Ann N Y Acad Sci 1974, 237(0):52-61.

141. Mackay-Sim A, Kittel PW: On the Life Span of Olfactory Receptor Neurons. Eur J Neurosci 1991, 3(3):209-215.

142. Rowley JC, Moran DT, Jafek BW: Tracer Studies of Microvillar Cells Suggest a 2Nd Morphologically Distinct Class of Sensory Neuron Exists in Mammalian Olfactory Epithelia. Chemical Senses 1987, I 2(4):692-692.

143. Rowley JC 3rd, Moran DT, Jafek BW: Peroxidase backfills suggest the mammalian olfactory epithelium contains a second morphologically distinct class of bipolar sensory neuron: the microvillar cell. Brain Res 1989, 502(2):387-400.

144. Eisthen HL: Evolution of vertebrate olfactory systems. Brain Behav Evol 1997, 50(4):222-233.

145. Carr VM, Farbman Al, Colletti LM, Morgan Jl: Identification of a New Nonneuronal Cell Type in Rat Olfactory Epithelium. Neuroscience 1991, 45(2):433-449.

146. Johnson EW, Eller PM, Jafek BW: An Immunoelectron Microscopic Comparison of Olfactory Marker Protein Localization in the Supranuclear Regions of the Rat Olfactory Epithelium and Vomeronasal Organ Neuroepithelium. Acta Oto-Laryngologica 1993, II3(6):766-77I.

147. Iwanaga T, Takahashiiwanaga $H$, Fujita $T$, Yamakuni T, Takahashi $Y$ : Immunohistochemical Demonstration of a Cerebellar Protein (Spot-35 Protein) in Some Sensory Cells of Guinea-Pigs. Biomedical Research-Tokyo 1985, 6(5):329-334.
148. Elsaesser R, Montani G, Tirindelli R, Paysan J: Phosphatidylinositide signalling proteins in a novel class of sensory cells in the mammalian olfactory epithelium. Eur J Neurosci 2005, 2 I ( I 0):2692-2700.

149. Costanzo RM, Graziadei PPC: A Quantitative-Analysis of Changes in the Olfactory Epithelium Following Bulbectomy in Hamster. Journal of Comparative Neurology I 983, 21 5(4):370-38I.

150. Graziadei GAM: Experimental Studies on the Olfactory Marker Protein. 3. The Olfactory Marker Protein in the Olfactory Neuroepithelium Lacking Connections with the Forebrain. Brain Research 1983, 262(2):303-308.

15I. Michel D, Moyse E, Brun G, Jourdan F: Induction of Apoptosis in Rat Olfactory Neuroepithelium by Synaptic Target Ablation. Neuroreport 1994, 5(I I): 1329-1332.

152. Asan E, Drenckhahn D: Immunocytochemical characterization of two types of microvillar cells in rodent olfactory epithelium. Histochem Cell Biol 2005, I 23(2): 157-168.

153. Yamagishi M, Ishizuka Y, Fujiwara M, Nakamura H, Igarashi S, Nakano Y, Kuwano R: Distribution of Calcium-Binding Proteins in Sensory Organs of the Ear, Nose and Throat. Acta Otolaryngol Suppl 1993, 506:85-89.

154. Hansel DE, Eipper BA, Ronnett GV: Regulation of olfactory neurogenesis by amidated neuropeptides. Journal of Neuroscience Research 200I, 66(I): I-7.

155. Hansel DE, Eipper BA, Ronnett GV: Neuropeptide $\mathbf{Y}$ functions as a neuroproliferative factor. Nature 200I, 4 I0(683 I):940-944.

156. Montani G, Tonelli S, Elsaesser R, Paysan J, Tirindelli R: Neuropeptide $\mathbf{Y}$ in the olfactory microvillar cells. Eur J Neurosci 2006 in press.

157. Paysan J, Bolz J, Mohler H, Fritschy JM: Gaba(a) Receptor AlphaI Subunit, an Early Marker for Area Specification in Developing Rat Cerebral-Cortex. Journal of Comparative Neurology 1994, 350(I): 133-149.

Publish with Bio Med Central and every scientist can read your work free of charge

"BioMed Central will be the most significant development for disseminating the results of biomedical research in our lifetime. "

Sir Paul Nurse, Cancer Research UK

Your research papers will be:

- available free of charge to the entire biomedical community

- peer reviewed and published immediately upon acceptance

- cited in PubMed and archived on PubMed Central

- yours - you keep the copyright
BiolMedcentral 